\title{
Burnout, Organizational Commitment and Turnover Intention
}

\author{
Arif Lukman Santoso \\ Faculty of Economics and Business \\ Sebelas Maret University, Indonesia \\ Sahbuddin Abdi Sitompul \\ The Audit Board of the Republic of Indonesia \\ Agus Budiatmanto \\ Faculty of Economics and Business \\ Sebelas Maret University, Indonesia
}

Keywords

burnout, organizational commitment, turnover intention

\begin{abstract}
The purpose of this study is to examine the effect of burnout and organizational commitment on turnover intentions. The respondents in this study were auditors of the Audit Board of Republic of Indonesia (BPK) and The Finance and Development Supervisory Agency (BPKP). This study used convenience sampling method; the number of samples used in this study amounted to 326 auditors, consisting of 194 BPK auditors and 132 BPKP auditors. The methods used in data collection were the primary method of data collection, using questionnaires filled out directly by the survey respondents, while the data processing methods used was multiple linear regressions analysis. The result showed that burnout had positive effect on auditor turnover intention and organizational commitment had negative effect on auditor turnover intention.
\end{abstract}

Corresponding author: Arif Lukman Santoso

Email addresses for corresponding author: ariflukmans@staff.uns.ac.id

First submission received: $30^{\text {th }}$ November 2017

Revised submission received: $1^{\text {st }}$ February 2018

Accepted: 25 th March 2018

\section{Introduction}

Auditor is one of the professions that have high levels of job switching (Suwandi and Indriantoro, 1999). Not only auditors who work on Public Accounting Firm, auditors working in government agencies such as the Audit Board of Indonesia (BPK) and the Financial and Development Supervisory Agency (BPKP) also have labor turnover intentions. Public Accounting Firms can conduct employee turnover easily and quickly if there are employees who relocate. Meanwhile, at BPK and BPKP, shifting employee can be a difficult problem since the status of the auditors in BPK and BPKP are the State Civil Apparatus. BPK and BPKP cannot directly recruit a replacement for outgoing auditor. Recruitment policy is not the absolute authority of BPK and BPKP, but it must get approval from the central government through the Ministry of Administrative Reform. If there has been approval from the Ministry of Administrative Reform to recruit employees, the time required to perform the selection of employees is also very long. Not to mention the time of education and training for new employees who have passed the selection to be auditor.

Every year BPK loses a lot of auditors because there are the auditors who retired, died and resigned. The number of BPK auditors who resigned is relatively high. The data obtained from BPK internal human resources information system (sisdm.bpk.go.id), over the last ten years (until February 2016) there were at least 145 BPK auditors who resigned. To replace the retired, died and resigned auditors, BPK should recruit new auditors. However due to the civil servant recruitment moratorium policy which was issued by the Central Government, BPK RI could not recruit new auditors. In Government Performance Reports (LAKIP) BPK RI in 2014, one of the challenges that hinder BPK in achieving predetermined performance targets is that the demand and expectations of the stakeholders on 
BPK assessment continues to rise, but it is not followed by an increase in BPK human resources significantly due to the civil servant's recruitment moratorium set by the government.

To prevent the decrease in BPK auditors, the desire of the auditors to switch job should be minimized. The high rate of employee turnover can be predicted by how much the desire owned by employees to switch job is. Unlike the factors of the auditors who retired and died that cannot be prevented and the civil servant recruitment moratorium which cannot be predicted when it would be repealed by the central government, hence the desire to switch job of the auditors can be predicted and prevented by the leaders of BPK and BPKP. There are many reasons why the auditors have a desire to switch job, one of which is the issue of burnout. Burnout is defined as a syndrome of emotional exhaustion, depersonalization and low sense of self accomplishment that leads to a decrease in effectiveness of the work (Maslach and Jackson, 1981). A research conducted by Herda (2012) states that the demands of the job can create burnout on auditors and a high level of turnover intention.

Another factor that can influence the auditors to have a desire to switch job is the organizational commitment. Moynihan and Pandey (2007) argue that organizational commitment is a variable that is often tested in the study of turnover intention because the organization's commitment signifies a real relationship between the employee and the company. In addition, Meyer and Allen (1991) states that an employee who has a strong commitment is a person who has the least desire to switch job.

\section{Literature review and hypothesis development}

\subsection{Burnout}

Burnout is a syndrome of emotional exhaustion and cynicism that often occurs among people who work (Maslach and Jackson, 1981). Maslach, Leiter and Schaufeli (2008) states that burnout has three main dimensions in response to interpersonal stress namely: (1) Emotional Fatigue (Emotional Exhaution), which is a major aspect of the syndrome of burnout, is an increase in emotional exhaustion which leads to a sense of overextend and physical and emotional exhaustion. (2) Depersonalization is a representation of the interpersonal context of burnout. Depersonalization leads to negative feelings toward others, do not have the feeling/ lack of respect towards others or too often provide a response to all aspects of the work. (3) Decline in Work Performance (Lack of accomplishment), is a representation of self-evaluation dimension of burnout. This dimension gives the tendency to evaluate themselves negatively. The decline in job performance leads to feelings of incompetent and achievement and productivity decline in work.

According to Pines and Aronson (1988), the cause of burnout are among others: (1) an excessive workload, (2) lack of feedback from superiors, (3) a bad relationship with peers and superiors and (4) no opportunity to develop themselves. The symptoms of someone suffering from burnout according to Pines and Aronson (1988) are as follows: (1) feel very tired and lethargic, (2) a decrease in enthusiasm both within and outside the work environment, (3) the increasing reliance on food and medicines containing excessive alcohol and compulsive, (4) Limiting oneself from family and friends, (5) The tendency to dream about an escape to eliminate the unpleasant situation and fantasize about a place that can give you satisfaction and peace. (6) The increasing impatience, (7) Deteriorating health.

According to Maslach and Jackson (1981), burnout has serious potential implications for staff, clients and institutions in which they interact. The research on this syndrome leads to a decrease in quality of care or services provided by the staff. This can be a factor causing employee turnover, absenteeism, and low morale. Further it is said that burnout seems to be correlated with various indices associated with personal distress, including physical fatigue, insomnia, increased use of alcohol and drugs, marital and family problems. The same thing was concluded by Burke (1987) on the impact that can be caused by burnout among others, large symptoms of psychosomatic, excessive negative feelings, decreasing job satisfaction, great conflicts of work and non-work, high desire to switch job, less healthy life style (e.g. alcohol, caffeine, and rarely exercise) and symptoms of deteriorating health (ego, high blood pressure, absence due to illness, on medication).

\subsection{Organizational Commitment}

Porter, Steers and Boulian (1974) defines organizational commitment as an individual identification force against one's involvement in a particular organization, which is generally characterized by at least 
three factors: (1) a strong belief in accepting goals and values of the organization, (2) the desire to exert every effort for the sake of the organization; (3) a strong desire to maintain the organization membership.

Meyer and Allen (1991) divide the organizational commitment into 3 types: (1) Affective Commitment, an organizational commitment that arises because of the emotional attachment, desire of employees to engage and identify themselves with the company because of the value suitability in the company. In this case the employee resides in an organization because of his own will. (2) Continuance commitment, a commitment to organization based on considerations about what must be sacrificed when one is leaving the organization or their fears of losing outstanding benefits in the company where he works. In this case the employee decides to stay in the organization because he considers it as a fulfillment. (3) Normative Commitment, an organizational commitment in the form of employee beliefs about his responsibilities to the company. This commitment arises because the employees feel obligated to stay at the company. The obligation to be loyal to the company making the employees chose to remain in the company.

\subsection{Switching Desire}

The desire to switch job is the intention of employees to stop working in the company (Zeffane, 1994). Robbins and Judge (2015) explain that the desire to switch job is a voluntary or involuntary withdrawal from an organization. Voluntary turnover is an employee's decision to leave the organization voluntarily caused by a factor of how interesting the current work is, and the availability of other employment alternatives. Conversely, involuntary turnover or dismissal illustrates the employer's decision to terminate the employment relationship and is uncontrollable for employees who experience it.

Turnover intention brings a lot of negative effects for the company. Newstrom (2013) explains that excessive employee turnover can have some negative effects on the organization, including: (1) the rising employee termination costs in the form of interview cost of employees who want to quit and employee severance payments, (2) the increase in training costs for new employees in the form of skills development in both formal and informal, (3) the increased costs incurred as a result of vacancies in the organization, in the form of temporary assistance and overtime costs. The temporary vacancy can also result in productivity lost and disruption of service, (4) the rising costs for employees replacement, in the form of fees for recruiting, interviewing and placement of new employees, (5) the existence of a moral effect, for the employees left, could be loss of companionship and for the organization may be changes in disrupted work patterns until a replacement for the leaving employee is found. Another negative impact on the organization if many employees resigned is that the organization's reputation can be damaged in society.

\section{Hypothesis development}

\subsection{Influence of burnout on turnover intentions}

The results of the study of Lin et al. (2013) states that burnout is associated with various forms of withdrawal from work such as absenteeism, desire to leave the job and then switch job. Goodman and Boss (2012) states that employees who changed jobs had significantly higher burnout dimension scores than that of the employees who remain in the organization. Based on the above presentation, burnout effect on turnover intentions can be formulated into the following hypothesis:

$\mathrm{H}_{1}$ : Burnout has a positive effect on turnover intentions

\subsection{The influence of organizational commitment on turnover intentions}

The result of Hollingworth and Valentine (2013) research states that organizational commitment and turnover intentions have a strong negative relationship. Schwepker, Jr. (1999) states that employees with a lower organizational commitment have a greater turnover intention. Based on the above presentation, the effect of organizational commitment on turnover intentions can be formulated into the following hypothesis:

$\mathrm{H}_{2}$ : Organizational commitment negatively affects turnover intentions

\subsection{Research Model}

Based on the formulation of the hypotheses that have been outlined, then the model of this study is as follows: 
Independent Variable

Dependent Variable

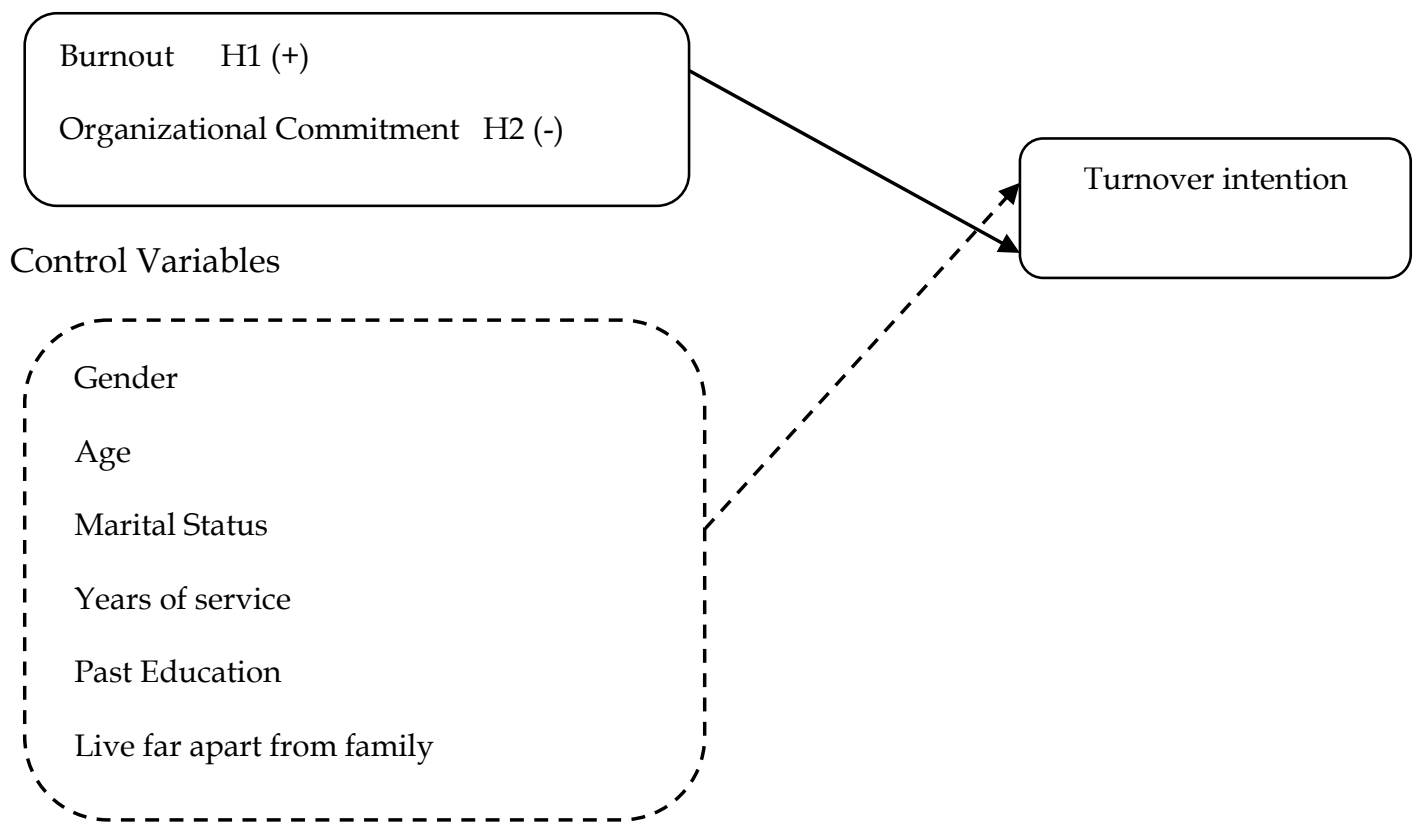

\section{Methods}

\subsection{Collecting Data Method}

In this study, primary data were used as the data source. The method used in the collection of primary data in this study was survey method. The data were obtained by distributing questionnaires directly to the respondents, the BPK and BPKP auditors. The data sources in this research were the score of each variable indicator obtained from questionnaires filled out by the BPK and BPKP auditors.

The population and the sample were the auditors who worked at BPK and BPKP both who served at headquarters and in offices. The minimum number of samples to be examined for each group of respondents was 30 people. The samples in this study were selected by using convenience sampling technique.

\subsection{Operational Definition and Measurement of Variables}

\subsubsection{Independent Variable}

Independent variables used in this study were:

4.2.1.1 Burnout

Burnout is a syndrome of emotional exhaustion and cynicism that often occurs among people who work (Maslach and Jackson, 1981). Burnout was measured using the Maslach Burnout Inventory (MBI) developed by Maslach (1981). MBI used in this study consists of 22 questions consisting of 14 positive questions and 8 negative questions. Questions with positive value are contained in Question $1,2,3,5,6,8,10,11,13,14,15,16,20$ and 22 while the negative questions are contained in questions number $4,7,9,12,17,18,19$ and 21 .

\subsubsection{Organizational Commitment}

Organizational commitment is a psychological condition that binds employees to an organization so as to reduce the desire to move (Meyer and Allen, 1991). Organizational commitment Instruments consists of seven items of questions with 7 Likert points scale adopted from Utami and Bonussyeani (2009). Respondents were asked to choose the alternative answers on a scale of 1 (strongly disagree) to 7 (strongly agree at all). From the seven of these questions, there are three positive questions, they are questions number 3.5 and 7 , and there are four negative questions, namely the questions number 1,2,4 and 6. 


\subsubsection{Dependent Variable}

The dependent variable in this research is the turnover intention. The turnover intention is the intention of employees to stop working in the company (Zeffane, 1994). The turnover intention was measured with the instrument of Utami and Bonussyeani (2009), which consists of eleven items of questions with a 7-point Likert scale. Respondents were asked to choose the alternative answers on a scale of 1 (strongly disagree) to 7(strongly agree at all). From eleven of these questions, there is one negative question, namely question number 9 .

\subsubsection{Control Variables}

Control variables in this study were gender, age, marital status, past education, years of service and live far away from the family.

\subsection{Data Analysis Method}

The technique of the data testing in this research was multiple linear regression analysis, with the form of the following equation:

\begin{tabular}{|c|c|c|c|}
\hline \multicolumn{4}{|c|}{ Description: } \\
\hline KB & : Turnover intention & JK & : Gender \\
\hline $\mathrm{U}$ & : Age & $\mathrm{SP}$ & : Marital Status \\
\hline PT & : Last Education & MK & : Years of service \\
\hline TBK & : Live with family & $\mathrm{a}$ & : Constant \\
\hline BO & : Burnout & $\mathrm{KO}$ & : Organizational Commitment \\
\hline
\end{tabular}

e : confounding variables (Error

Before doing the regression analysis, data quality testing (validity and reliability), data normality test and classical assumption were conducted first.

\section{Results and discussion}

\subsection{Results of Data Collection}

The research data were collected through questionnaires directly distributed by visiting the respondents and also through an online questionnaire that were distributed directly to the respondents via whatsapp, also through whatsapp group, facebook or e-mail. The questionnaire distribution and retrieval were conducted for approximately 2.5 months that from February 1, 2016 until April 15, 2016. The complete respondents' data can be seen in Table 5.1

\begin{tabular}{lllll}
\multicolumn{2}{l}{ Table 5.1-Questionnaires Description } & & \\
\hline Respondent's & Returned & Damaged & Used & Usable Data (\%) \\
Work unit & Questionnaires & Questionnaires & Questionnaires & \\
\hline BPK & 194 & 0 & 194 & 100 \\
BPKP & 132 & 4 & 128 & 97 \\
Total & 326 & 4 & 322 & 98 \\
\hline
\end{tabular}

Source: Processed Primary Data

\subsection{Descriptive statistics}

The description of the variables is shown in Table 5.2 as follows:

Table 5.2-Descriptive statistics

\begin{tabular}{llllll}
\hline & $\mathrm{N}$ & Minimum & Maximum & Mean & Deviation Std \\
\hline \hline Burnout & 322 & 1,00 & 4,05 & 2,540 & 0,419 \\
$\begin{array}{l}\text { Organizational } \\
\begin{array}{l}\text { Commitment } \\
\text { Turnover Intention }\end{array}\end{array}$ & 322 & 2,14 & 7,00 & 4,786 & 0,824 \\
\hline Prof & 1,09 & 6,09 & 3,059 & 0.840 \\
\hline
\end{tabular}

Source: Processed Primary Data

\subsection{Hypothesis testing}

The technique for testing the hypothesis in this study is multiple linear regression analysis. The data used in the regression analysis has passed data quality tests both the validity test and reliability test. Regression analysis in this study has met the normality test and was free from classical assumption of 
multicollinearity, autocorrelation and heteroscedasticity test. The results of regression testing are shown in Table 5.3 below:

Table 5.3-Multiple Linear Regression Testing Results

\begin{tabular}{|c|c|c|c|}
\hline Sample & Model & $\mathrm{B}$ & Sig. \\
\hline \multirow[t]{11}{*}{$\mathrm{BPK}$ and $\mathrm{BPKP}$} & Constant & 3,953 & 0.000 \\
\hline & $\mathrm{U}$ & 7.347 & 0,996 \\
\hline & JK & $-0,114$ & 0,164 \\
\hline & SP & $-0,020$ & 0,811 \\
\hline & PT & 0,096 & 0,106 \\
\hline & MK & 0,000 & 0,985 \\
\hline & TBK & $-0,198$ & $0,016^{*}$ \\
\hline & $\mathrm{BO}$ & 0,531 & $0,000^{* *}$ \\
\hline & $\mathrm{KO}$ & $-0,476$ & $0,000^{* *}$ \\
\hline & Adj. $R^{2}$ & 0,437 & \\
\hline & F Value & 32,135 & $0,000^{* *}$ \\
\hline \multirow[t]{11}{*}{ BPK } & Constant & 2.897 & 0,000 \\
\hline & $\mathrm{U}$ & 0,013 & 0,410 \\
\hline & JK & $-0,113$ & 0,227 \\
\hline & SP & $-0,013$ & 0,904 \\
\hline & PT & 0,196 & $0,011^{*}$ \\
\hline & MK & $-0,010$ & 0,536 \\
\hline & TBK & $-0,166$ & 0,089 \\
\hline & $\mathrm{BO}$ & 0,632 & $0,000^{* *}$ \\
\hline & $\mathrm{KO}$ & $-0,431$ & $0,000^{* *}$ \\
\hline & Adj. $R^{2}$ & 0,430 & \\
\hline & F Value & 19,235 & $0,000^{* *}$ \\
\hline \multirow[t]{11}{*}{ BPKP } & Constant & 5,290 & 0,000 \\
\hline & $\mathrm{U}$ & $-0,025$ & 0,542 \\
\hline & JK & $-0,005$ & 0,977 \\
\hline & SP & $-0,007$ & 0,960 \\
\hline & PT & $-0,009$ & 0,948 \\
\hline & MK & 0,028 & 0,449 \\
\hline & TBK & $-0,266$ & 0,088 \\
\hline & $\mathrm{BO}$ & 0,389 & $0,018^{*}$ \\
\hline & $\mathrm{KO}$ & $-0,534$ & $0,000^{* *}$ \\
\hline & Adj. $\mathrm{R}^{2}$ & 0,437 & \\
\hline & F Value & 13,317 & $0,000^{* *}$ \\
\hline
\end{tabular}

Information: ${ }^{* *}=$ significant at the $1 \%,{ }^{*}=$ significant at the $5 \%$

Source: Processed Primary Data

For the combined sample of the BPK and BPKP auditors, Table 5 shows that the adjusted R-square is 0.437. This shows that the turnover intention of the BPK and BPKP auditors can be explained by burnout variable and organizational commitment amounted to $43.7 \%$, while the remaining $46.3 \%$ is explained by other variables outside the equation model in this study. Simultaneous test results can be seen from the $\mathrm{F}$ value of 32.135 with a probability value of 0.000 . The probability test value which is less than $5 \%$ indicates that the research model is fit. For partial test, burnout had a significant positive influence on turnover intentions, while the organizational commitment and living far apart from the family has a significant negative impact on turnover intentions. It can be seen from the probability values of the variables which are less than $5 \%$.

For the BPK samples, Table 5.3 shows that the adjusted R-square is 0.430 . This shows that the turnover intention of the BPK and BPKP auditors can be explained by burnout variable and organizational commitment by $43 \%$, while the remaining $47 \%$ is explained by other variables outside the equation model in this study. Simultaneous test results can be seen from the F value of 19.235 with a probability value of 0.000 . The probability test value which is less than $5 \%$ indicates that the research model is fit. For partial test, burnout and last education have a significant positive influence on turnover intentions, while the organizational commitment has a negative significant impact on turnover intentions. 
For the BPKP samples, Table 5.3 shows that the adjusted R-square is 0.437 . This shows that the turnover intention of the BPK and BPKP auditors can be explained by burnout and organizational commitment by $43.7 \%$, while the remaining $46.3 \%$ is explained by other variables outside the equation model in this study. Simultaneous test results can be seen from the F value of 13.317 with a probability value of 0.000 . The probability test value is less than $5 \%$ indicates that the research model is fit. For partial test, burnout has a significant positive influence on turnover intentions, while the organizations commitment has a significant negative impact on turnover intentions.

\subsection{Discussion}

Based on the results of statistical tests that have been described previously, further discussion of each of these hypotheses is described in more detail as follows:

\subsubsection{The influence of burnout on turnover intentions}

Based on the multiple regression test model, it is obtained that in this study, burnout has a significance level below $5 \%$ both in the combined samples of the BPK and BPKP auditors and in the BPK or BPKP auditor samples only. This means that the first hypothesis is accepted. Burnout has a positive effect on turnover intentions, either on the BPK or BPKP auditors.

This study is consistent with the results of a research conducted by Herda (2012) which shows that burnout can produce a great desire to switch job for the auditors. In addition, a research by Mansor (2012) which shows that burnout has a significant impact on the auditor's turnover intentions.

\subsubsection{The influence of organizational commitment on turnover intentions}

Based on the regression test model result in this study, the organizational commitment has a level of significance below 5\% both on the combined samples of the BPK and BPKP auditors and the BPK or BPKP auditor samples only. This means that the second hypothesis is accepted. Organizational commitment negatively affects the auditors' desire to switch job, both on the BPK and BPKP auditors.

This study is consistent with the results of a research conducted by Hollingworth and Valentine (2013) and by Sow (2015), each of which shows that organizational commitment has negative effect on turnover intentions.

\section{Conclusions and limitations}

This study examined the effect of burnout and organizational commitment on turnover intentions of auditors. The findings of this research show that Burnout has positive effect on turnover intentions. This research also finds that organizational commitment has negative effect on turnover intentions.

The limitation of this study is only using burnout and organizational commitment variables to predict turnover intention behavior. While there are other variables that may affect the auditors' intentions to switch job like job satisfaction, work conflict, role ambiguity, leadership behaviors, organization culture, and satisfactory wage. Future researches need to investigate the effect of these variables on turnover intention.

\section{References}

Burke, Ronald J. (1987). Burnout in Police Work: An Examination of the Cherniss Model. Group and Organization Studies, 12 (2): 174-188

Goodman, Eric A. and R. Wayne Boss. (2002). The Phase Model of Burnout and Employee Turnover. Journal of Health and Human Services Administration, 25 (1): 33-47

Herda, David N. (2012). Auditors' Relationship with Their Accounting Firm and Its Effect on Burnout, Turnover Intention, and Post-Employment Citizenship. Current Issues in Auditing, 6 (2): 13-17

Hollingworth, David and Sean Valentine. (2014). Corporate Social Responsibility, Continuous Process Improvement Orientation, Organizational Commitment and Turnover Intentions. International Journal of Quality \& Reliability Management, 31 (6): 629-651

Hudaib, Muhammad and TE, Cooke. (2005). The Impact of Managing Director changes and Financial Distress on Audit Qualification and Auditor Switching. Journal of Business Finance and Accounting, 32 (9 \& 10): 1703-1739

Lin, QH, Jiang, CQ and Lam TH. (2013). The Relationship bbetween Occupational Stress, Burnout, and Turnover Intention among Managerial Staff from a Sino-Japanese Joint Venture in Guangzhou, China. Journal of Occupational Health, 55 (6): 458-467 
Mansor, Nurul Akma. (2012). The Effects of Job Satisfaction, Burnout and Organizational Culture on Auditor's Turnover Intention. Dissertation, Shah Alam: Universiti Teknologi Mara. Retrieved from: http://www.proquest.com

Maslach, Christina and Susan E Jackson. (1981). The Measurement of Experienced Burnout. Journal of Occupational Behavior, 2 (2): 99-113

Maslach, Christina., Leiter, Michael P., and Schaufeli, Wilmar. (2008). The Oxford Handbook of Organizational Wellbeing, Chapter 5: Measuring Burnout. New York: Oxford University Press

Meyer, John P. and Allen, Natalie J. (1991). A Three-Component Conceptualization of Organizational Commitment. Human Resouces Management Review, 1 (1): 61-89

Moynihan, Donald P. and Pandey, Sanjay K. (2007). The Ties That Blind: Social Networks, Person-Organization Value Fit, and Turnover Intention. Journal of Public Administration Research and Theory, 18: 205-227

Newstrom, Jhon W. (2011). Organizational Behavior. New York: McGraw Hill

Pines, A., \& Aronson, E. (1988). Career burnout: Causes and cures. New York: Free Press.

Porter, Lyman W., Richard M. Steers and Paul V. Boulian. (1974). Organizational Commitment, Job Satisfaction and Turnover aamong Psychiatric Technicians. Journal of Applied Psychology, 59 (5): 603-609

Robbins, Stephen P. and Timothy A. Judge. (2015). Organizational Behavior. New Jersey: Pearson Education Inc.

Schwepker Jr, Charles H. 1999. The Relationship between Ethical Conflict, Organizational Commitment and Turnover Intentions in the Salesforce. Journal of Personal Selling and Sales Management, 19 (1): 43-49

Sow, Mouhamadou Thile, (2015). Relationship Bebween Organizational Commitment and Turnover Intentions aamong Healthcare Internal Auditors. Dissertation, Minnesota: Walden University. Retrieved from: http://www.proquest.com

Suwandi and Indriantoro, Nur. (1999). The Testing of Pasewark and Strawser Turnover Models, Empirical Studies in the Environment of Public Accountants <Pengujian Model Turnover Pasewark dan Strawser, Studi Empiris pada Lingkungan Akuntan Publik>. Jurnal Riset Akuntansi Indonesia, 2 (2): 173-195

Utami, Intiyas and Bonussyeani, Nur ES. (2009). The Effect of Job Insecurity, Job Satisfaction, and Organizational Commitment to Turnover Intention <Pengaruh Job Insecurity, Kepuasan Kerja, dan Komitmen Organisasional terhadap Keinginan Berpindah>. Jurnal Akuntansi dan Keuangan Indonesia. 6 (1): 117-139

Zeffane, Rashid. (1994). Understanding employee Turnover: The Need for a Contigency Approach. International Journal of Manpower, 15 (9/10): 22-37 